\title{
Pengembangan Kemampuan Bahasa Reseptif Anak Usia Dini dalam Memperkenalkan Bahasa Inggris melalui Flash Card
}

\author{
Syah Khalif Alam ${ }^{\varpi_{1}}$, Ririn Hunafa Lestari ${ }^{2}$ \\ Pendidikan Guru Pendidikan Anak Usia Dini, Institut Keguruan dan Ilmu Pendidikan (IKIP) \\ Siliwangi \\ DOI: $\underline{10.31004 / \text { obsesi.v4i1.301 }}$
}

\begin{abstract}
ABSTRAK
Pemerolehan bahasa pada anak usia dini dimulai melalui pendengaran yang anak dengar di sekitarnya yang disebut dengan bahasa reseptif. Tujuan dari penelitian ini untuk mengetahui media pembelajaran yang dapat mengembangka bahasa reseptif anak dalam memperkenalkan bahasa Inggris sebab anak yang hidup di zaman 21 dituntut untu menjadi generasi yang siap bersaing secara internasional. Penelitian menggunakan pendekatan penelitian kualitatif dengan desain studi kasus di salah satu sekolah di Cimahi. Setelah dilakukan penelitian, peneliti memperoleh hasil bahwa sekolah tersebut menggunakan flashcardsebagai media pembelajaran dalam mengembangkan bahasa reseptif yaitu mendengar dan membaca sebab anak-anak memperhatikan kosakata dan mengucapkan kembali kosa kata tersebut dengan proses membaca gambar flashcard. Maka dari itu,flashcarddiperlukan guru dalam mengembangkan kemampuan bahasa anak khususnya dalam mengembangkan bahasa reseptif dalam memperkenalkan bahasa Inggris.
\end{abstract}

Kata Kunci: flash cards; bahasa reseptif; anak usia dini; bahasa inggris

\begin{abstract}
Obtaining language in early childhood begins through hearing that children hear around them called receptive language. The purpose of this study is to find out learning media that can develop children's receptive language in introducing English because children who live in the 21st age are required to be a generation that is ready to compete internationally. The study used a qualitative research approach with a case study design in one of the schools in Cimahi. After doing research, the results obtained using flashcards as a learning medium develop receptive language that is listening and reading the reasons children pay attention to vocabulary and re-read these words with the process of reading flashcard images. Based on these results the researchers concluded that the flashcard is needed by the teacher in developing children's language skills, especially in developing receptive language in introducing English.
\end{abstract}

Keywords: flash cards; receptive languages; early childhood; english language.

Copyright (c) 2019 Syah Khalif Alam, Ririn Hunafa Lestari

$\triangle$ Corresponding author :

Email Address : khalif@ikipsiliwangi.ac.id ( Bandung, Indonesia )

Received 10 October 2019, Accepted 25 November 2019, Published 26 November 2019 


\section{PENDAHULUAN}

Kemampuan bahasa memiliki peranan penting bagi kehidupan individu, khususnya pada anak usia dini (Wahyudin \& Mubiar. 2011; Astuti \& Habibah. 2015), sebab bahasa merupakanupaya anak menyatakan pikiran dan perasaan kepada orang lain sebagai lawan berbicara (Wahyudin \& Agustin, 2011; Astuti \& Habibah, 2015).

Pada masa kanak-kanak, kemampuan bahasa memiliki tingkat kemudahan dalam menerima dan memahami pengetahuan yang baru dibandingkan dengan perkembangan logika (Jazuly, 2015), dikarenakan salah satu karakteristik anak adalah meniru sehingga ketika orang dewasa berbicara, anak akan mengamati bagaimana pelafalan dari kata-kata tersebut.

Menurut Myklebust (dalam Hernawati, 2007) menyatakan bahwa pemerolehan bahasa anak diperoleh dari pengalaman anak yang mendengar terhadap lingkungan terdekatnya. Proses penerimaan bahasa yang melalui indera pendengaran adalah bahasa reseptif. Bahasa reseptif diperoleh dari pengalaman belajar anak yangmenghubungkan lambang bahasa yang diperolehnya melalui pendengaran yang bertujuan untuk memahami mimic dan nada suara yang kemudian mengerti arti kata. Setelah itu anak-anak mulai berkomunikasi dengan menggabungkan ekspresi wajah, gerakan tubuh dan akhirnya melalui kata-kata untuk diungkapkan atau yang disebut dengan bahasa ekspresif.

Berdasarkan hasil lapangan, anak-anak hidup di abad 21 dimana anak dituntut untuk bersaing secara internasional sehingga berdampak pada kemampuan berbahasa anak di masa yang akan datang khususnya bahasa asing (Wasitohadi. TT; Chang, 2012).bahwa Salah satu bahasa internasional yang perlu dikuasai adalah bahasa Inggris. Bahasa Inggris telah menjadi bahasa yang hampir digunakan oleh banyak negara di dunia untuk berkomunikasi, sehingga penguasaan bahasa Inggris perlu diperhatikan bagi masyarakat modern untuk memperluas informasi yang dibutuhkan di dunia internasional (Sophya, 2014; Jazuly, 2015). Hal ini sesuai dengan hasil lapangan yang dilakukan Liyana \& Kurniawan, (2019) guru yang khusus mengajarkan bahasa Inggris di Taman Kanak-kanak masih minim.

Memperkenalkan bahasa Inggris dapat dilakukan sejak dini, sebab kemampuan bahasa anak sangat pesat, dimulai dengan mempelajari simbol atau gambar yang menjelaskan lingkungan disekitarnya serta memiliki keuntungan dalam kemampuan mengingat dan menghapal dalam waktu yang cukup lama (Asilestari, 2016; Scheffler, 2015;Muñoz, 2009). Dalam pembelajarannya anak mendengarkan atau menyimak setiap kosakata yang diucapkan oleh guru setelah mendengarkan anak akan mulai mencoba mengucapkan kosakata yang telah diucapkan.

Pada masa kanak-kanak, tugas guru dalam mengajarkan bahasa Inggris sebatas pengenalan seperti huruf-huruf, angka, buah-buahan, anggota badan, warna, serta percakapan sederhana dan mudah seperti good morning, how are you?, how do you feel?, dan lain-lain (Jazuly, 2015). Adapun cara pengajaran bahasa Inggris yang akan menarik bagi anak selain bermain yaitu lagu, cerita dan keterampilan yg melibatkan fisik motorik serta menggunakan media flash card (Astuti \& Habibah, 2015).

Berdasarkan hasil pengamatan yang dilakukan di salah satu sekolah yang ada di Cimahi, terdapat salah satu program pembelajaran yang memperkenalkan bahasa Inggris mulai dari usia tiga sampai enam tahun. Dalam pembelajaran bahasa Inggris, guru menggunakan berbagai macam media pembelajaran ketika mengajarkan bahasa Inggris seperti video pembelajaran, flash card, dan keyboard.

Fokus penelitian tersebut dibatasi dalam lingkup yang kecil yaitu bagaimanamedia pembelajaran untuk mengembangkan bahasa reseptif dalam memperkenalkan bahasa Inggris sejak dini?, sehingga tujuan dari penelitian tersebut untuk mengetahui media pembelajaran bahasa Inggris yang dapat digunakan serta memberikan informasi kepada guru sebagai pendidik ketika akan mengajarkan anak bahasa Inggris khususnya bahasa reseptif, sebab guru merupakan sumber daya manusia yang memiliki peranan penting 
dalam menciptakan suasana pembelajaran yang menyenangkan untuk mewujudkan tujuan pendidikan nasional (Alam, 2018).

Pada anak usia dini, perkembangan bahasa ditekankan pada kemampuan mendengar dan berbicara. Kemampuan anak untuk belajar bahasa khususnya bahasa asing dapat diperkenalkan sekitar usia dua sampai enam tahun, sebab pada usia ini perkembangan bahasa anak sangat pesat mulai dari simbol-simbol untuk menggambarkan lingkungan sekitarnya. Salah satu bahasa asing yang dapat diperkenalkan kepada anak adalah bahasa Inggris. Menurut Stakanova \& Tolstikhina (2014) menyatakan bahwa memperkenalkan bahasa Inggris sebagai foreign language dapat diperkenalkan sejak dini. Memperkenalkan bahasa Inggris sejak dini lebih baik dibadingkan dengan anak-anak yang bersekolah dasar. Kemampuan berbahasa Inggris dapat dikelompokkan menjadi proses bahasa yang meliputi mendengar dan membaca dan menghasilkan kemampuan berbicara dan menulis sebagai hasil dari proses bahasa (Basheer Nomass, 2013)

Selain kemampuan mendengar, berbicara, membaca dan menulis terdapat lingkup kebahasaan yang perlu diperhatikan yaitu komponen kosakata, pelafalan dan stuktur kata (Sophya, 2014).Mengajarkan bahasa Inggris kepada anak dibutuhkan media pembelajaran untuk menyampaikan materi pembelajaran yang telah disusun (Sophya, 2014).

Berdasarkan hasil pemaparan di atas, diharapkan bahwa penggunaan flash card dapat digunakan oleh guru dalam mengembangkan kemampuan reseptif anak usia dni dalam memperkenalkan bahasa Inggris seperti memperkenalkan berbagai macam vocabullary yang dibuat dalam bentuk kegiatan permainan yang diulang.

\section{METODOLOGI}

Penelitian ini dilaksanakan dengan pendekatan kualitatif dipilih sebab penelitian adalah ingin mengungkapkan secara lebih rinci dan jelas tentang pembelajaran bahasa Inggris untuk anak usia dini di Sekolah kota Cimahi. Penelitian ini menggunakan pendekatan kualitatif dengan menggunakan pendekatan penelitian studi kasus dikarenakan penelitian ini ingin mengkaji dan menjelaskan suatu program, kejadian, aktivitas, proses, individu atau sekolompok individu secara mendalam, menyeluruh, bermakna, intesif dan alamiah (sesuai dengan kondisi) sebagai satu kesatuan dalam parameter tertentu seperti tempat dan waktu yang spesifik ((Emzir, 2012; Hancock \& Algozzine, 2006; Creswell, 2014) Pada penelitian kualitatif, peneliti merupakan instrument utama yang memiliki peranan penting dalam mengumpulkan data di lapangan melalui observasi atau wawancara (Nasution, 1996). Data kualitatif diperoleh dari berbagai sumber seperti hasil pengamatan (mulai dari nonpartisipan hingga partisipan), wawancara (dari yang tertutup hingga terbuka), dokumen (dari yang bersifat pribadi hingga yang bersifat publik) dan bahan audiovisual (mencakup foto, CD, dan VCD) (Creswell, 2014; Hancock \& Algozzine, 2006).

Penelitian ini menggunakkan teknik analisis tematik. Teknik analisis tematik adalah cara mengidentifikasi tema-tema yang muncul pada penelitian dan merupakan bagian penting untuk mendeskripsikan fenomena tersebut (Dewi, 2016; Azis, 2016).

\section{HASIL DAN PEMBAHASAN}

\section{Hasil Penelitian}

Berdasarkan hasil temuan penelitian diperoleh hasil bahwa media pembelajaran yang sudah digunakan dalam memperkenalkan bahasa Inggris pada Program English Day meliputi media yang dapat diindera oleh anak usia prasekolah, dalam hal ini visual (benda riil (jika ada), video, animasi, gambar), flash card, lagu-lagu yang setema dengan tema hari tersebut. Adapun hasil wawancara yang telah dilakukan, yaitu:

"Media yang dapat diindera oleh anak usia prasekolah, dalam hal ini visual (benda riil (jika ada), video, animasi, gambar), flash card, lagu-lagu yang setema dengan tema hari tersebut."

(Hasil wawancara dengan narasumber 2)" 
"Medianya bisa pakai flash card, bisa pakai watching atau nonton lalu dengan musik dan instruksi sebagai media yang sangat tepat."

(Hasil wawancara dengan narasumber 1)

Hal ini diperkuat dengan hasil pengamatan pada kegiatan inti program English Day salah satunya guru menggunakan media pembelajaran yang nyata untuk memperkenalkan suatu konsep.

“...guru 1 menggunakan media asli yaitu newspaper, book, magazine, dan letter"

(Pengamatan pada tema pembelajaran komunikasi)

"Setelah itu anak-anak diajak guru 1 melihat dan merasakan water, wind dan fire dalam bentuk nyata."

(Pengamatan pada tema pembelajaran air, udara dan api) flashcard:

Selain hasil wawancara, adapun kegiatan pembelajaran bahasa Inggris dengan media

"Guru 1 mulai memperkenalkan FC shape kepada anak satu per satu dimulai dengan memperkenalkan circle, rectangle, triangle, heart, star dan yang terakhir adalah square. Setiap satu FC, guru 1 memperkenalkan kepada satu persatu anak. Ketika anak sudah mendapatkan gilirannya guru 1 meminta semua anak untuk mengucapkan FC terseebut bersam-sama sebanyak lima kali.

Guru 1: "say all together five times, circle (anak berkata: "circle"), circle (anak berkata: "circle"), circle (anak berkata: "circle"), circle (anak berkata: "circle"), circle(anak berkata: "circle")" sambil menunjukkan jarinya sebagai alat bantu ajar ketika menghitung serta menunjukkan ekspresi muka yang jelas.Ketika melafalkan anak dibimbing oleh guru 1 dan 2. Pada kata circle yang kelima anak-anak mulai menaikkan nada bicaranya. Tahapan pembelajaran pada kegiatan ini berlaku pada FC shape selanjutnya.

"Setelah memperkenalkan lagi di papan tulis guru 1 mulai mengajak anak untuk bernyanyi agar anak-anak lebih mudah untuk mengingat semua FC.

Guru 1: "circle, triangle, rectangle, star, square, heart, those are shape." Lagu ini bernada kan lagu. Nyanyian tersebut dinyanyikan sebanyak \pm 3 kali. Setelah selesai menyanyikannya guru 1 meminta anak untuk menyanyikan lagu tersebut di depan papan tulis sambil menunjuk FC yang dimbing oleh guru 1 dan guru 2.

Berdasarkan hasil pengamatan proses belajar mengajar, peneliti melihat bahwa bahasa reseptif anak yang meliputi kemampuan mendengar terlihat dari kegiatan guru memperkenalkan flaschcard dengan cara mengucapkan vocabulary dengan bantuan flashcard secara tepat dan jelas, serta kemampuan membaca yang dilihat dari kegiatan anak menunjukkan flashcard sesuai dengan vocabulary-nya.

\section{Pembahasan}

Berdasarkan hasil penelitian yang telah dilakukan di atas, media pembelajaran yang diterapkan Sekolah tersebut meliputi media audio seperti lagu yang diiringi olehkeyboard, media visual seperti flash card, media nyata dan media audio visual seperti video pembelajaran yang sesuai. Hal ini sesuai dengan jenis media untuk memperkenalkann bahasa Inggris terdiri dari media audio yang menyampaikan pesan melalui suara dan bunyi untuk merangsang perhatian, perasaan, dan kemampuan anak untuk memahami isi tema sepert musik. Yang ke dua adalah media visual seperti gambar diam, media grafis (gambar dan tulisan), media model dan media realita dan media audio-visual yang memberikan pesan melalui suara, gambar dan tulisan atau media pandang dengar seperti televisi, film dan video pendidikan (Dewi. 2017; Sophya, 2014). 
Hasil dari analisis data, peneliti memfokuskan hasil penelitian kepada media pembelajaran untuk memperkenalkan bahasa Inggris untuk anak usia dini yaitu flash card sebab terlihat bahwa anak fokus terhadap gambar sehingga guru dapat mengembangkan kemampuan menyimak dan mendengar ketika guru menjelaskannya. Menurut(Jazuly, 2015, hal. 226) selama kegiatan pembelajaran dengan menggunakan flash card, anak-anak menyukai media pembelajaran yang bersifat visual seperti flash card yang dibuat menarik dan menyenangkan.

Melalui flash card, guru memperkenalkan berbagai macam vocalbulary dengan kegiatan pengulangan yang dibuat dalam bentuk permainan. Flash card merupakan media pembelajaran yang sering digunakan guru dalam mengajarkan vocabulary. Flash card adalah potongan kertas atau kardus yang terdiri dari gambar, kata, atau kalimat sederhana (Shehadeh \& Farrah, 2016).

Ketika anak belajar melalui flash card, anak-anak akan melihat, mendengar dan menyimak pelafalan kata yang ditunjukkan oleh guru melalui flash card, dengan tujuan anak mampu mengucapkan kembali vocabulary tersebut. Dalam kegiatan pelafalan kosa kata, peneliti melihat bahwa terdapat proses menyimak dan membaca gambar atau simbol yang anak lihat dari flash card tanpa adanya keterangan tulisan yang dibuat oleh guru, sehingga penggunaan flash card dapat meningkatkan motivasi anak untuk belajar bahasa Inggris dan memahami kosakata dengan mudah(Sitompul, 2013). Pembelajaran menggunakan flash card memiliki keunggulan seperti mengajarkan kosakata dan stuktur kalimat baru, mengembangkan pemahaman suatu konsep dan meningkatkan kemampuan membaca serta mampu membuat suasana pembelajaran untuk anak-anak menjadi aktif dan antusias (Tan \& Nicholson, 1997; Taghizadeh et al., 2015; Sitompul, 2013; Tirtayani, Magta, \& Lestari, 2017).

\section{SIMPULAN}

Berdasarkan hasil penyataan di atas, flash card yang digunakan ketika pembelajaran berlangsung memiliki peranan penting dalam mengembangkan bahasa reseptif anak usia dini. Terlihat dari proses kegiatan pembelajan yang mengembangkan bahasa resptif yaitu kemampuan mendengar atau menyimak ketika anak melihat dan mendengar guru memeperkenalkan flashcard serta mengembangkankemampuan membaca ketika anak diminta untuk mengucapkan kembali vocabulary melalui flashcard.

\section{UCAPAN TERIMAKASIH}

Ucapan terima kasih kepada Rektor Institut Keguruan dan Ilmu Pendidikan (IKIP) Siliwangi, Wakil Rektor I, II dan III, Dekan Fakultas Ilmu Pendidikan, Ketua Prodi PGPAUD, dan rekan kerja yang telah memotivasi peneliti dalam melakukan penelitian dengan baik serta guru dan anak-anak PG-TK @Delft's Education sebagai tempat dilakukannya penelitian.

\section{DAFTAR PUSTAKA}

Alam, S. K. (2018). Efforts To Increase The Teacher's Group Teacher Competency Through The Teacher Work Groups In Central Bakung Cimahi. Jurnal Ilmiah P2M STKIP Siliwangi P2M STKIP Siliwangi, 5(2), 1-6. DOI: 10.22460/p2m.v5i2p106-113.1061

Asilestari, P. (2016). Komputer Interaktif Sebagai Media Pengajaran Bahasa Inggris Pada Anak Usia Dini. Jurnal Paud Tambusai, 2(1), 55-62. DOI: 10.31004/obsesi.v2i1.59

Astuti, W., \& Habibah, U. (2015). Peningkatan Kemampuan Kosakata Bahasa Inggris Anak Melalui Metode Pembelajaran Interaktif Di Kelompok A TK Pertiwi I Jirapan 2014/2015. Prosiding Seminar Nasional Dan Call For Papers, ISBN: 978-(2), 323-332.

Azis, A. (2016). Pemanfaatan Komputer dalam Proses Pembelajaran Anak Usia Dini. Universitas Pendidikan Indonesia.

Basheer Nomass, B. (2013). The Impact of Using Technology in Teaching English as a Second 
DOI: 10.31004/obsesi.v4i1.301

Language. English Language and Literature Studies, 3(1), 111-116. https://doi.org/10.5539/ells.v3n1p111

Chang, S.-Y. (2012). Young Learner English Language Policy and Implementation: International Perspectives edited by Janet Enever, Jayne Moon and Uma Raman. World Englishes, 31(3), 406-408. https:/ / doi.org/10.1111/j.1467-971x.2012.01766.x

Creswell, J. (2014). Penelitian Kualitatif $\mathcal{E}$ Desain Riset Memilih Diantara Lima Pendekatan. Yogyakarta: Penerbit Pustaka Pelajar.

Dewi, E. K. (2016). Pemanfaatan Komputer dalam Proses Pembelajaran Anak Usia Dini. Universitas Pendidikan Indonesia.

Emzir. (2012). Metodologi Penelitian Pendidikan Kuatitatif \& Kualitatif. Jakarta: Rajagrafindo Persada.

Hancock, D. ., \& Algozzine, R. (2006). Doing Case Study Research: A Pratical Guide for Beginning.

Hernawati, T. (2007). Pengembangan Kemampuan Berbahasa Dan Berbicara Anak Tunarungu. Juni, 7(1), 101110.

Jazuly, A. (2015). Peran bahasa inggris pada anak usia dini. Prosiding SimposiumNasional Riset Pendidikan II, (10).

Liyana, A., \& Kurniawan, M. (2019). Speaking Pyramid sebagai Media Pembelajaran Kosa Kata Bahasa Inggris Anak Usia 5-6 Tahun. Jurnal Obsesi : Jurnal Pendidikan Anak Usia Dini, 3(1), 225. https:// doi.org/10.31004/obsesi.v3i1.178

Muñoz, C. (2009). Input and long-term effects of early learning in a formal setting. The Age Factor and Early Language Learning, 141-160. https://doi.org/10.1515/9783110218282.141

Nasution, S. (1996). Metode Penelitian Naturalistik Kualitatif. Bandung: Penerbit Tarsito.

Scheffler, P. (2015). Introducing very young children to English as a foreign language. International Journal of Applied Linguistics (United Kingdom), 25(1), 1-22. https://doi.org/10.1111/ijal.12035

Shehadeh, I. I. A., \& Farrah, M. A. A. (2016). The Effectiveness of Using Children 's Songs in Developing Elementary Graders ' English Vocabulary and Pronunciation in Jerusalem, Palestine. Creative Practices in Language Learning and Teaching (CPLT), 4(2).

Sitompul, E. Y. (2013). Teaching Vocabulary Using Flashcard and Word List. Journal of English and Education, 1(1), 52-58.

Sophya, I. V. (2014). Desain Pembelajaran Bahasa Inggris Untuk Pendidikan Anak Usia Dini. ThufuLA: Jurnal Inovasi Pendidikan Guru Raudhatul Athfal, 2(2), 251. https://doi.org/10.21043/thufula.v2i2.4639

Stakanova, E., \& Tolstikhina, E. (2014). Different Approaches to Teaching English as a Foreign Language to Young Learners. Procedia - Social and Behavioral Sciences, 146, 456-460. https://doi.org/10.1016/j.sbspro.2014.08.154

Taghizadeh, M., Street, H., Square, R., Vaezi, S., Street, H., Square, R., ... Square, R. (2015). Digital Games, Songs and Flashcards and their Effects on Vocabulary Knowledge of Iranian Preschoolers, 156-171.

Tan, A., \& Nicholson, T. (1997). Flashcards Revisited: Training Poor Readers to Read Words Faster Improves Their Comprehension of Text. Journal of Educational Psychology, 89(2), 276-288. https://doi.org/10.1037/0022-0663.89.2.276

Tirtayani, L. A., Magta, M., \& Lestari, N. G. A. M. Y. (2017). Teacher Friendly E-Flashcard: a Development of Bilingual Learning Media for Young Learners. Journal of Education Technology, 1(1), 18. https:/ / doi.org/10.23887/jet.v1i1.10080

Wahyudin, U., \& Agustin, M. (2011). Penilaian Perkembangan Anak Usia Dini Panduan Guru, Tutor, Fasilitator dan Pengelola Pendidikan Anak Usia Dini. Bandung: PT. Refika Aditama. 